\title{
Contrasted hydrological systems of the Peruvian Amazon induce differences in growth patterns of the silver arowana, Osteoglossum bicirrhosum
}

\author{
Fabrice DUPONCHELLE ${ }^{1,2,3, a}$, Adela RUIZ ARCE ${ }^{1,4}$, Annelore WATY ${ }^{1,2,4}$, Jacques PANFILI $^{5}$, \\ Jean-François RENNO ${ }^{1,2,4}$, Filomena FARFAN ${ }^{1,3}$, Aurea GARCIA-VASQUEZ ${ }^{1,4}$, Fred CHU KOO ${ }^{1,4}$, \\ Carmen GARCIA DAVILA ${ }^{1,4}$, Gladys VARGAS ${ }^{1,4}$, Almilcar ORTIZ ${ }^{6}$, Ricardo PINEDO ${ }^{6}$ \\ and Jesus NUÑEZ ${ }^{1,2,3}$
}

1 Laboratoire mixte international, Evolution et Domestication de l'Ichtyofaune amazonienne (LMI - EDIA), Centro de Investigaciones Quistococha. Programa AQUAREC, Iquitos-Loreto, Perú

2 Institut de Recherche pour le Développement (IRD), Institut des Sciences de l'Evolution de Montpellier (UMR 5554-ISEM), Université Montpellier 2, CC 065, 34095 Montpellier Cedex 5, France

3 Universidad Nacional Federico Villareal, FOPCA, 350 calle Roma, Miraflores, Lima, Perú

${ }^{4}$ Instituto de Investigación de la Amazonía Peruana (IIAP), Iquitos-Quistococha, Perú

5 Institut de Recherche pour le Développement (IRD), UMR 5119 ECOSYM (Ecologie des Systèmes marins côtiers), BP 1386, 18524 Dakar, Senegal

6 Instituto Nacional de Desarrollo (INADE). Proyecto Especial de Desarrollo Integral de la Cuenca del Putumayo (PEDICP). Call Brasil, $3^{\text {ra }}$ cuadra, Iquitos, Peru

Received 24 June 2011; Accepted 20 March 2012

\begin{abstract}
In Amazonian fisheries, the silver arowana, Osteoglossum bicirrhosum (Cuvier 1829) is heavily exploited for human consumption as an adult, and for the aquarium trade as a small juvenile (yolk sac juvenile mainly). The periodicity of annuli formation on otoliths and growth variability of the silver arowana were studied in different river river-basins of the Peruvian Amazon between 2006 and 2009. Transverse stained sections of 606 individual otoliths were analysed from four different river-basins, the Amazonas, Ucayali, Napo and Putumayo, of which 554 could be interpreted. These belonged to 274 females ranging from 15 to $91 \mathrm{~cm}$ (standard length) and 280 males ranging from 30 to $91 \mathrm{~cm}$. In addition, yolk sac juveniles of known age were collected to improve growth modelling. Monthly proportions of stained otolith edges validated the formation of a single annulus per year in two different river-basins with lagged hydrological cycles: the Amazonas-Ucayali and the Putumayo. Stained growth mark counts resulted in a longevity estimate of at least 16 years for the silver arowana in the Peruvian Amazon. This fish grew quickly during the first two years, and asymptotic growth was reached after four to five years, except in the Putumayo where it was reached slightly earlier. Results showed no significant growth dimorphism between sexes within basins, but indicated significant growth differences among river basins. Silver arowanas measured, on average, between 38 and $40 \mathrm{~cm}$ at the end of their first year. Length-at-age differences among river basins increased with age to reach over $14 \mathrm{~cm}(\mathrm{and}>3 \mathrm{~kg})$ after 7 years between the faster and slower growing populations (Amazonas and Putumayo, respectively). The growth differences observed emphasize the need for further investigation on the population structure of this species as, although these differences might merely be phenotypic responses to contrasted environmental conditions, they could alternatively reflect the existence of several populations with distinct genetic and life history characteristics. The consequences of such differences would be very important for the management and conservation of this fragile and extensively exploited species.
\end{abstract}

Key words: Tropical freshwater fish / Floodplain / Otolith / Von Bertalanffy growth function / Length-at-age / Intra-specific growth differences / Osteoglossidae / Amazon

\footnotetext{
a Corresponding author: fabrice.duponchelle@ird.fr
} 


\section{Introduction}

The increased exploitation of wild fish for the aquarium trade has become an important conservation issue (Andrews 1990; Moreau and Coomes 2007). The trade of ornamental fish species is a growing activity, generating over three billion USD in annual retail sales, and is $90 \%$ reliant on freshwater species, most of which come directly from natural environments (Olivier 2001). This is particularly the case in South America, where almost all exported specimens are caught in the wild (Olivier 2001). The aquarium trade has already contributed to local extinctions of fish populations, especially in South East Asia (Ng and Tan 1997). This is the case for the Asian arowanas, Scleropages spp., whose natural populations have been so dramatically reduced that they were listed under the Convention on International Trade in Endangered Species (CITES) Appendix I in 1975 (Moreau and Coomes 2006). Since then, their very similar-looking Amazonian cousin, Osteoglossum bicirrhosum, the silver arowana, is replacing Scleropages spp. on Asian markets and its exportation has increased alarmingly since the 1990s (Tello and Canepa 1991; Moreau and Coomes 2006, 2007). Mean annual exports increased from 708613 to 1200785 fingerlings between 1999 and 2007, for corresponding annual revenues of 309067 to 1136705 USD (Alcántara et al. 2007). As a result of the growing demand, prices per larva in Iquitos (Peru) gradually increased from USD 0.41 in 1999 to USD 1.33 in 2007 (Alcántara et al. 2007).

Together with the blue arowana (Osteoglossum ferreirai) and the giant paiche or pirarucu (Arapaima gigas), the silver arowana $(O$. bicirrhosum) is the only other South American member of the archaic order Osteoglossiformes, characterised by a bony tongue, large ossified scales and laterally-compressed bodies (Goulding 1980). The silver arowana is a sedentary, relatively large fish ( 1 m total length), preferentially inhabiting lentic water bodies of the Amazon river basin, Rupununi and Oyapock rivers (Goulding 1980; Bayley and Petrere 1989; Reis et al. 2003; Saint-Paul et al. 2000). In Amazonian fisheries, it is exploited as an adult for human consumption and as a small juvenile (most of the time still with its yolk sac) for the ornamental trade (Moreau and Coomes 2006; Alcántara et al. 2007). The species has exceptionally low fecundity and large eggs (Goulding 1980; Queiroz 2008), with extended parental care (male mouth-brooding). Its position high in the food web, implying a relatively low abundance, makes it unable to withstand high fishing pressure (Moreau and Coomes 2006). As a direct consequence of the increasing exploitation by the ornamental trade, the silver arowana is believed to be threatened in Peru (Moreau and Coomes 2006, 2007), it has already been placed on the Red Book list of Colombia (Mojica et al. 2002) and its trade for ornamental purposes is prohibited in Brazil (Carvalho de Lima and Prang 2008; Prang 2008).

Despite its economic and ecological importance in the Amazon basin (Alcántara et al. 2007; Ortíz and Iannacone 2008), the natural populations of this species are still relatively poorly studied and the basic knowledge needed for proper management is often lacking (Moreau and Coomes 2006). The feeding and breeding ecology of the silver arowana were recently described in the Mamirauá Reserve in Brazil (Chaves et al. 2008; Mascarenhas 2008; Queiroz 2008). However, accurate and precise information on its growth and mortality patterns, both essential for fisheries management and conservation, are still poorly documented. Some preliminary information on $O$. bicirrhosum from the Mamirauá Reserve was provided based on scale analyses (Cavalcante 2004, 2008), but the methods used for growth estimation were inadequately described and therefore not reproducible. Another study in the Mamirauá Reserve used length frequency analyses to estimate growth and mortality (Lucena et al. 2008) and is the only detailed reference on the species to date. The present work aimed to test the use of otoliths as precise tools for studying growth characteristics of $O$. bicirrhosum. Additionally, given the sedentary nature of the species and the relationship between its breeding season and the hydrological cycle (Goulding 1980; Queiroz 2008), we tested the hypothesis that there are growth differences among some of the main river-basins of the Peruvian Amazon (Amazonas, Ucayali, Napo, Putumayo), some of which have lagged hydrological regimes.

\section{Material and methods}

\subsection{Fish sampling}

Fish were collected monthly between November 2006 and April 2009 at the Iquitos and Requena markets for the Amazonas, Ucayali and Napo river-basins (Fig. 1). Requena is an important market located on the lower Ucayali River and Iquitos is the main landing market of the Peruvian Amazon, concentrating fishes from the Amazonas, Ucayali, Marañon, Napo, Huallaga, Tigre, Putumayo, Nanay, Yavari and Morona rivers (Garcia et al.2009). To optimise accuracy about specimen provenance, fish (of the largest possible size range) were bought only from specific providers from each river basin. For the Putumayo, fish were bought monthly, from March 2008 to April 2009, from local fishermen in the Huapapa community (Fig. 1). The river basins were chosen on the basis of their hydrological cycles: the Amazonas and Ucayali rivers have very similar hydrological cycles; the Putumayo and Napo also have similar hydrological cycles, but lagged about three months behind those of the Amazonas-Ucayali. The availability and reliability of specimen provenance was also taken into account. In the four river-basins, fishermen mainly caught the fish using gill nets of mesh size between $6.4 \mathrm{~cm}$ and $12.7 \mathrm{~cm}$ (2.5 and 5 inches). Occasionally, fish were caught using harpoons or bows.

As exploitation of $O$. bicchirosum for the ornamental trade concerns juveniles with their yolk sac (hereafter refer to as "yolk sac juveniles"), we collected 10 yolk sac juveniles from the Ucayali and 10 from the Putumayo rivers to improve growth modelling. 


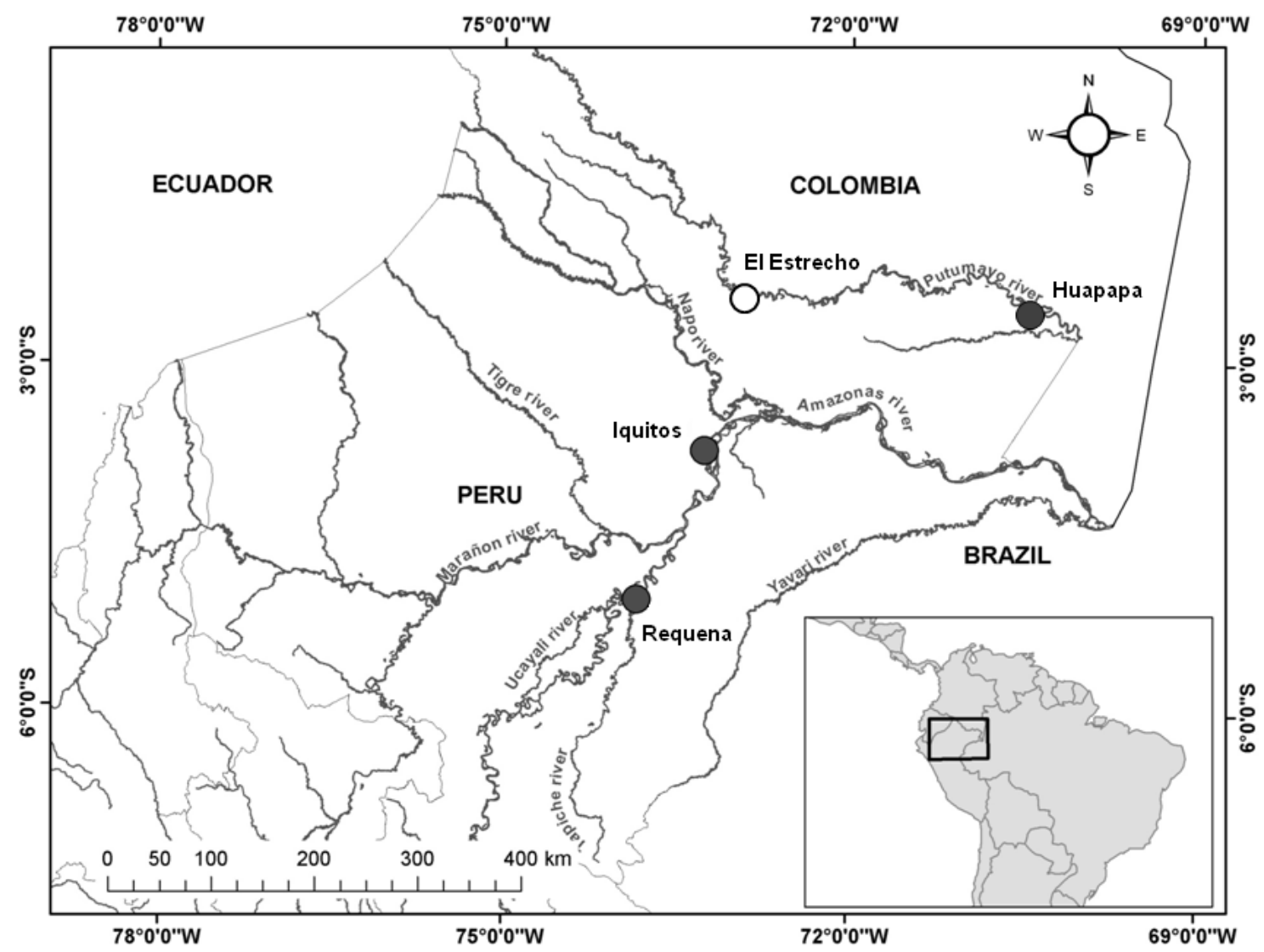

Fig. 1. Map of the collection sites in the Peruvian Amazon (black circles). The white circle corresponds to the hydrological station at El Estrecho on the Putumayo river.

\subsection{Biological sample analysis}

The standard length (SL, cm) and body mass ( $\mathrm{g}$ ) of each fish were measured to the nearest millimetre and gram, respectively. The sagittal otoliths (sagittae, Fig. 2) were extracted, washed in water, dried and stored in referenced envelopes for later laboratory processing.

Age and growth characteristics were determined from the examination of 606 individual transverse otolith sections passing through the core (Fig. 2). After sectioning, they were polished (using $1200 \mu \mathrm{m}$ paper, then $1 \mu \mathrm{m}$ alumin powder) and stained with toluidine blue ( $1 \%$, for one hour) after acid etching (ethylenediaminetetraacetic acid 5\%, for $10 \mathrm{~min}$ ), following the method described for other Amazonian species (Loubens and Panfili 1995, 1997, 2001, 2003; Duponchelle et al. 2007). Stained marks, corresponding to translucent seasonal increments (Panfili et al. 2002), were interpreted and counted along the otolith dorso-ventral axis. The otolith edge was described as stained, opaque or undetermined in order to validate the timing of mark deposition by calculating the monthly proportion of stained edges. For this process, otoliths forming their first stained mark (which usually forms during an extended, non-representative period) and otoliths of old specimens (in which the nature of the edge was difficult to determine because the stained marks were very close together), were excluded from the analysis. After the validation stage, stained marks were enumerated for individual age estimation. The last stained mark was not counted if it was on the otolith margin, and thus in the process of formation. The individual age in months was then calculated taking into account the date of capture, the number of stained marks and the mean hatching date for the populations: November for the Amazonas and Ucayali, January for the Napo (Ruiz Arce 2011) and March for the Putumayo (Waty unpublished data). Otoliths were independently interpreted twice by two readers and Chang's coefficient of variation (CV, Chang 1982) was calculated (Panfili et al. 2002). When the CV was over 10\%, the otolith was re-interpreted and discarded if the CV was not improved (Loubens and Panfili 1997).

For the estimation of the mean observed length-at-age, age groups were determined as follows: age-group 1 corresponded to fish whose calculated age was between 0.5 and 1.4, age-group 2 corresponded to fish whose calculated age was between 1.5 and 2.4 years, and so on. Owing to reduced numbers, fish of 5 and 6 years old were pooled. Fish that were older than 7 years when the asymptotic part of the growth curve was reached were also pooled.

\subsection{Hydrological data}

Data on the hydrological cycles of the river basins were provided by the ORE-HYBAM (Observatoire régional, 


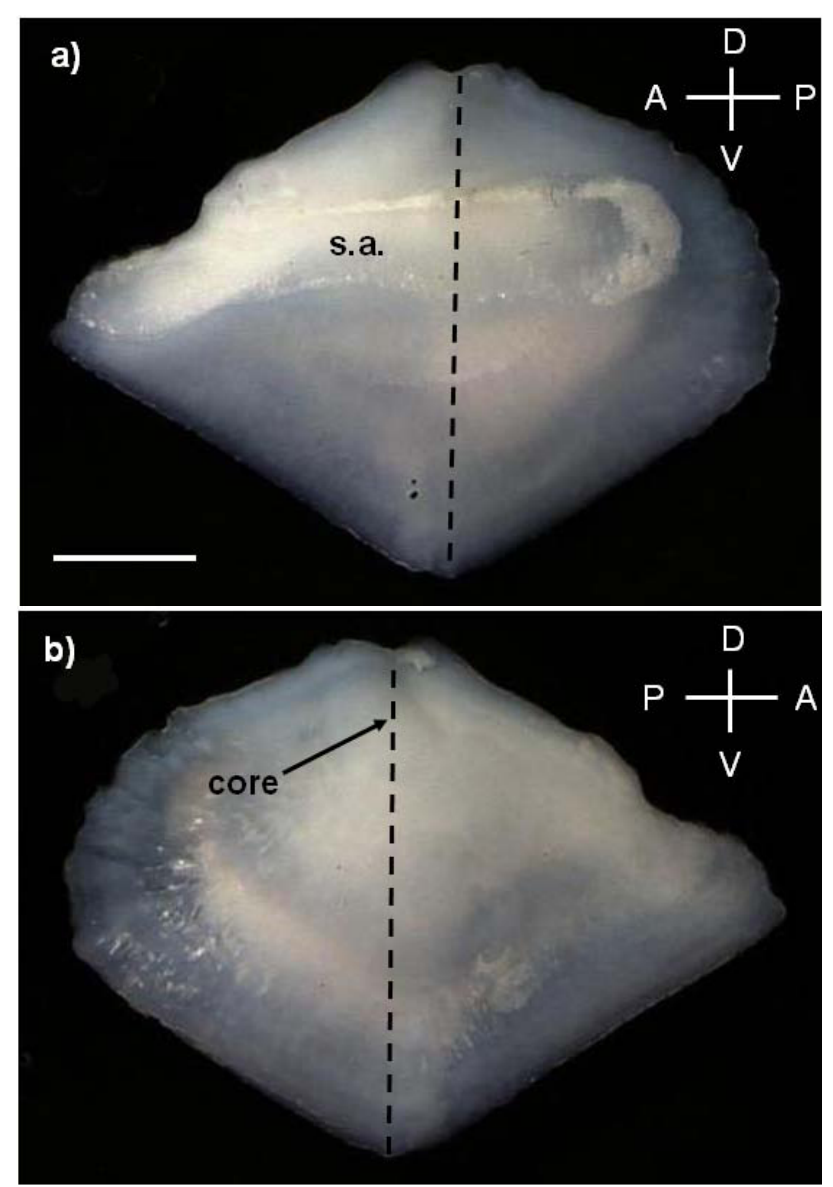

Fig. 2. Whole sagittal otolith (a: proximal side; b: distal side) of Osteoglossum bicirrhosum captured in Ucayali river (female, $48 \mathrm{~cm}$ SL, 700 g). A: anterior, D: dorsal, V: ventral, P: posterior, s.a.: sulcus acusticus. The dotted line indicates the location of a transverse section passing through the core. Scale bar $=2.5 \mathrm{~mm}$.

Hydrologie du bassin Amazonien) and SENAMHI (Servicio Nacional de Meteoloría e Hidrología, Peru). The data came from the Iquitos station, for the Amazonas river-basin, from Requena for the Ucayali river-basin and from El Estrecho for the Putumayo river-basin (Fig. 1).

\subsection{Statistical analyses}

Potential growth differences among sexes within each river basin were tested using the mean observed length-at-age data (Table 2) and $t$-tests (or Mann-Whitney rank sum tests when assumptions of normality and equal variance of distributions were not met) for every age-group (1, 2, 3, 4, 5-6 and >7 years).

The von Bertalanffy growth function (VBGF) was calculated using a non-linear estimation (quasi-Newton method) following the equation:

$$
L=L_{\infty}\left(1-\exp \left(-K\left(t-t_{0}\right)\right)\right.
$$

where $L$ is the mean standard length at age $t, L_{\infty}$ the asymptotic length, $K$ the growth coefficient and $t_{0}$ the theoretical age at size 0 .
VBGF parameters were compared among river basins using the likelihood ratio test (Tomassone et al. 1993) and applying the weighted sum of squares of Kimura (1980). For $k$ populations, the likelihood ratio test $S_{M L}$ was compared with $\chi^{2}$ using 3 degrees of freedom ( 3 parameters):

$$
S_{M L}=\sum_{i=1}^{k} n_{i} \times\left[\ln \left(s_{c}^{2}\right)-\ln \left(s_{k}^{2}\right)\right]
$$

where $n_{i}$ is the number of individuals of the $k$ th population, $s_{c}^{2}$ is the residual variance of the pooled model (for all populations), and $s_{k}^{2}$ is the residual variance of the models of the $k$ populations. The same likelihood ratio test was used for pairwise comparisons of the growth models, applying the Bonferroni correction when more than two pairwise-tests were performed.

Growth comparisons among river basins were also assessed using the mean observed length-at-age data (Table 2) and ANOVAs (or Kruskal-Wallis ANOVA on ranks when assumptions of normality and equal variance of distributions were not met) for every age-group.

\section{Results}

Over the study period, 606 otoliths of $O$. bicirrhosum were analysed, of which $52(8.6 \%)$ were discarded because they could not be interpreted. Out of the 554 otoliths interpreted, 161 were from the Amazonas (75 females and 86 males), 182 from the Ucayali (91 females and 91 males), 129 from the Napo (69 females and 60 males) and 82 from the Putumayo (39 females and 43 males) (Table 1). The mean CV of otolith readings was $2.7 \%$ in the Amazonas, $1.0 \%$ in the Ucayali, $1.0 \%$ in the Napo and $0.2 \%$ in the Putumayo river-basins.

\subsection{Otolith growth increment formation and validation}

Otoliths in $O$. bicirrhosum have a typical shape with a pronounced ventral dome (Fig. 2). The location of the core is difficult to establish due to the thickness of the otolith. A transverse section across the apex of the ventral and dorsal domes, however, generally passes through the core (Fig. 2). Characteristic otolith growth increments observed in transverse stained sections through the core are illustrated in Figure 3. In young specimens with no visible translucent zone, the chromophilic core is followed by a large opaque zone that occupies a large portion of the otolith (Fig. 3a). A first large aragonitic zone occupies a large portion of the otolith: it appears as a porous structure, which can irregularly incorporate some stain. At this early stage, the future first chromophilic (translucent) increment, which is comprised of several fine stained marks, can already be seen on the dorsal side. Later on, the first chromophilic increment (stained mark) surrounds the first aragonitic zone after the core (Fig. 3b). The second and subsequent stained marks form a annulus around the second large aragonitic zone and are, most of the time, also visible inside the sulcus acusticus (Figs. 3c, d). When the section passes right through the core, the first stained mark is also visible inside the sulcus acusticus (Fig. 3b). 
Table 1. Osteoglossum bicirrhosum. Standard length $(\mathrm{cm})$ and mass $(\mathrm{g})$ ranges, mean \pm standard deviation and number $(\mathrm{N})$ of females and males analysed in each river-basin.

\begin{tabular}{lcccccc}
\hline River-basin & Sex & $N$ & $\begin{array}{c}\text { Length range } \\
(\mathrm{cm})\end{array}$ & $\begin{array}{c}\text { Mean length } \pm \text { SD } \\
(\mathrm{cm})\end{array}$ & $\begin{array}{c}\text { Mass range } \\
(\mathrm{g})\end{array}$ & $\begin{array}{c}\text { Mean mass } \pm \text { SD } \\
(\mathrm{g})\end{array}$ \\
\hline Amazonas & Female & 75 & $28.5-90.9$ & $58.8 \pm 17.7$ & $170-8080$ & $2300 \pm 2040$ \\
& Male & 86 & $31.5-91.0$ & $62.6 \pm 18.6$ & $220-7360$ & $2690 \pm 2230$ \\
\hline Ucayali & Female & 91 & $15.9-82.7$ & $51.5 \pm 12.9$ & $30-4520$ & $1320 \pm 1050$ \\
& Male & 91 & $30.5-81.7$ & $48.5 \pm 11.9$ & $200-4620$ & $1060 \pm 890$ \\
\hline Napo & Female & 69 & $35.7-82.5$ & $54.1 \pm 10.2$ & $360-5430$ & $1410 \pm 940$ \\
& Male & 60 & $34.1-80.5$ & $54.3 \pm 10.7$ & $300-4280$ & $1380 \pm 880$ \\
\hline Putumayo & Female & 39 & $39.0-72.0$ & $62.1 \pm 8.3$ & $400-2450$ & $1680 \pm 540$ \\
& Male & 43 & $41.0-72.0$ & $62.3 \pm 8.5$ & $450-2500$ & $1700 \pm 590$ \\
\hline
\end{tabular}

Table 2. Osteoglossum bicirrhosum. Mean observed length-at-age \pm standard deviation, i.e. standard length, $\mathrm{cm}$ (number of fish used) for females, males, and females and males pooled in four river-basins of the Peruvian Amazon.

\begin{tabular}{|c|c|c|c|c|c|c|c|}
\hline & \multirow[b]{2}{*}{ River- basin } & \multicolumn{6}{|c|}{ Age (year) } \\
\hline & & 1 & 2 & 3 & 4 & $5-6$ & $>7$ \\
\hline & & \multicolumn{6}{|c|}{ Length-at-age, cm (number of specimens) } \\
\hline \multirow[t]{4}{*}{ Female } & Amazonas & $38.3 \pm 5.5(23)$ & $53.1 \pm 5.6(16)$ & $59.6 \pm 4.6(6)$ & $68.4 \pm 1.6(6)$ & $76.5 \pm 5.0(5)$ & $80.9 \pm 5.6(18)$ \\
\hline & Ucayali & $38.5 \pm 4.3(31)$ & $52.8 \pm 4.3(33)$ & $61.5 \pm 3.8(11)$ & $66.8 \pm 3.8(9)$ & $71.2 \pm 8.2(3)$ & $80.7 \pm 1.9(3)$ \\
\hline & Napo & $41.4 \pm 5.0(13)$ & $50.3 \pm 5.6(22)$ & $57.3 \pm 4.2(10)$ & $58.8 \pm 6.1(10)$ & $63.7 \pm 7.8(3)$ & $67.1 \pm 8.3(11)$ \\
\hline & Putumayo & & $46.5 \pm 7.1(4)$ & $60.0 \pm 4.0(3)$ & $60.7 \pm 6.0(7)$ & $66.3 \pm 3.1(7)$ & $68.4 \pm 2.4(8)$ \\
\hline \multirow[t]{4}{*}{ Male } & Amazonas & $38.9 \pm 4.0(23)$ & $55.9 \pm 5.3(23)$ & $61.0 \pm 5.3(9)$ & $70.9 \pm 0.6(2)$ & $80.6 \pm 5.5(11)$ & $84.2 \pm 3.6(20)$ \\
\hline & Ucayali & $39.5 \pm 5.5(46)$ & $53.5 \pm 4.5(33)$ & $61.6 \pm 5.0(5)$ & $71.3 \pm 4.8(4)$ & & $79.9 \pm 0.2(2)$ \\
\hline & Napo & $39.6 \pm 3.5(11)$ & $50.9 \pm 3.7(21)$ & $57.0 \pm 4.3(11)$ & $60.4 \pm 4.1(7)$ & $70.1 \pm 6.1(5)$ & $71.2 \pm 8.5(5)$ \\
\hline & Putumayo & & $46.5 \pm 5.9(4)$ & $60.5 \pm 7.7(4)$ & $61.9 \pm 6.8(10)$ & $66.7 \pm 4.2(9)$ & $68.0 \pm 3.7(6)$ \\
\hline \multirow[t]{4}{*}{ Both sexes } & Amazonas & $38.6 \pm 4.8(46)$ & $54.6 \pm 5.6(35)$ & $60.4 \pm 4.9(15)$ & $69.0 \pm 1.8(8)$ & $79.3 \pm 5.5(16)$ & $82.6 \pm 4.9(41)$ \\
\hline & Ucayali & $39.1 \pm 5.0(77)$ & $53.1 \pm 4.4(66)$ & $61.5 \pm 4.0(16)$ & $68.1 \pm 4.5(13)$ & $73.8 \pm 8.5$ (4) & $80.3 \pm 1.4(5)$ \\
\hline & Napo & $40.5 \pm 4.4(24)$ & $50.6 \pm 4.8$ & $57.1 \pm 4.2(21)$ & $59.4 \pm 5.3(17)$ & $67.7 \pm 7.0$ & $68.3 \pm 8.3(16)$ \\
\hline & Putumayo & & $46.5 \pm 6.1(8)$ & $60.3 \pm 5.9(7)$ & $61.4 \pm 6.3(17)$ & $66.5 \pm 3.7(16)$ & $68.2 \pm 2.9(14)$ \\
\hline
\end{tabular}

Chromophilic increments were interpreted as annuli because their formation-followed an annual pattern related to the hydrological cycle (Fig. 4). In Amazonas-Ucayali (the Ucayali and Marañon rivers unite to form the Amazon river) and Putumayo river-basins (Fig. 4), two river systems with lagged hydrological cycles (the maximum range in water levels is $8 \mathrm{~m}$ approximately), edge analysis validated the formation of a single annulus per year. The stained (translucent) increment was mainly formed during the dry and the early flooding periods, whereas the opaque zone formed during the period of rising and high waters. Seasonal growth variation was inferred from the relative widths of the two seasonal increments (stained translucent and opaque) on the otoliths, which had approximately equal formation times (Fig. 4). The formation of the translucent marks coincided with a period of reduced otolith growth, whereas the opaque zone corresponded to faster growth during more favourable conditions.

The annuli were frequently sub-divided (Fig. 3d), i.e., constituted of two or several stained bands, complicating the interpretation. Most of the time, the different bands converged along the distal side of the transverse section and could be identified as a single annulus (i.e., a composite annulus). In some specimens, the convergent point was not discernible or the distance among the composite bands was as large as the distance among two adjacent annuli, making interpretation impossible. These individuals were discarded from the analysis. In old specimens, besides the composite annuli, the main difficulty for interpreting the age was the reduced opaque zone between annuli, corresponding to decreased growth rate with increasing age. 

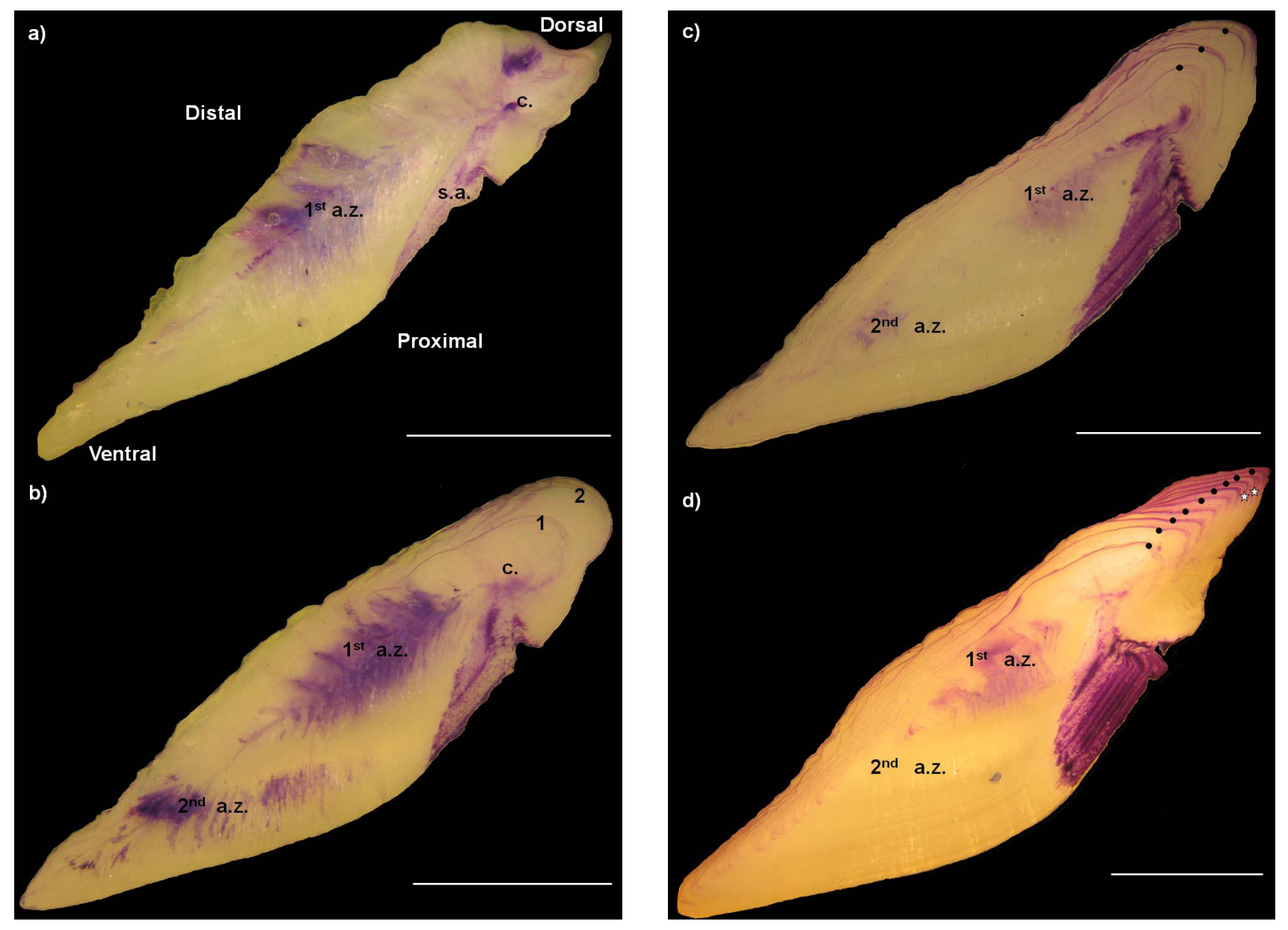

Fig. 3. Transverse stained sections of Osteoglossum bicirrhosum otoliths showing (a) no annulus, (b) two annuli, (c) three annuli plus one forming on the edge, (d) nine annuli. c.: core, a.z.: aragonitic zone, s.a.: sulcus acusticus, black dot: annulus, star: sub-divided annulus. Scale bar $=2.5 \mathrm{~mm}$.

\subsection{Growth}

The age of yolk sac juveniles was estimated between 2 weeks for the Putumayo (mean SL $=3.4 \pm 0.2 \mathrm{~mm}$ ) and 3 weeks for the Ucayali (mean SL $=4.9 \pm 0.3 \mathrm{~mm}$ ), following Argumedo (2005), Tang and Gomez (2005) and our own observations at the IIAP (Instituto de Investigaciones de la Amazonia Peruana) research centre in Iquitos (Nuñez et al., unpublished data). These durations are based on the average time elapsed between the newly hatched juvenile with a full yolk sac and the juvenile with a completely consumed yolk sac. The inclusion of yolk sac juveniles (YJ) in the samples allowed a better adjustment of the VBGF and hence a more precise growth description, especially during the first months. Modelling the growth of the O. bicirrhosum females from Ucayali river with or without the YJ (from the Ucayali) provided a good example (Fig. 5): $t_{0}$ varied from $-0.24 \pm 0.08$ without $\mathrm{YJ}$ to $-0.05 \pm 0.02$ with $\mathrm{YJ}$ and the theoretical size-at-age 0 was 9.6 and $2.3 \mathrm{~cm}$ without and with YJ, respectively. The size difference between the models with or without YJ was more pronounced at the youngest and oldest ages.

As YJ could not be obtained in the Amazonas or Napo, YJ from another river basin had to be used. In order to test for the effect of potential bias from using $\mathrm{YJ}$ from another river basin to reconstruct growth, we modelled the VBGF of the Ucayali females using both the Ucayali and the Putumayo YJ. The comparison of the two VBGF indicated no significant difference $\left(S_{M L}=2.966, d f=3, p>0.05\right)$ : the length-at-age variation ranged between $0.2 \mathrm{~mm}(0.03 \%$ at four years $)$ and $3.4 \mathrm{~mm}(0.5 \%$ at fourteen years). The potential bias was therefore considered insignificant. Thereafter, the Ucayali YJ were used for modelling the VBGF of $O$. bicirrhosum from the Amazonas and Napo.

$O$. bicirrhosum grew quickly during the first two years and the asymptotic phase of the growth curve was reached after four to five years, except in the Putumayo where it seemed to be reached after only three to four years (Fig. 6). Comparisons of the mean observed length-at-age among sexes (Table 2, $t$-tests) yielded no significant differences at any age for the Amazonas, Ucayali, Napo or Putumayo fishes. Subsequently, for further analyses, males and females were pooled within basins. The maximum observed age was 16 years in the Amazonas, with a mean age of $4.0 \pm 3.3$ years ( \pm standard deviation); max 14 years in the Ucayali river, with a mean age $2.0 \pm 1.7$ years, max 15 years in the Napo, with a mean age of $3.5 \pm 2.9$, and 13 years 

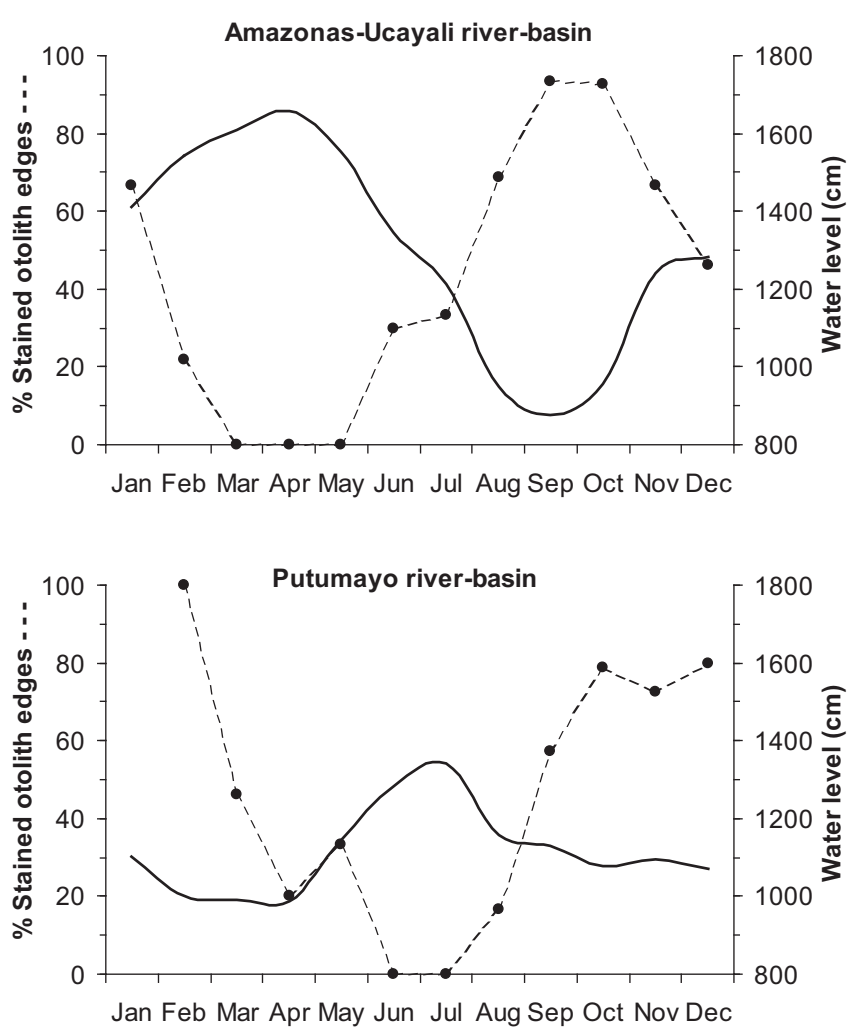

Fig. 4. Periodicity of annulus formation, based on the proportion of stained otolith edges (---), in relation to the hydrological cycle (smoothed line).

in the Putumayo, with a mean age of $5.0 \pm 2.6$. Depending on the river-basin, $O$. bicirrhosum reached 38 to $40 \mathrm{~cm}$ on average at one year, except in the Putumayo where this age group could not be sampled. Among-river-basin, mean observed size-at-age differences increased quickly with age to reach up to $14.3 \mathrm{~cm}$ between the Amazonas and Napo after 7 years (Fig. 6, Table 2). The modelled VBGF parameters were $L_{\infty}=83.3 \pm 0.8 \mathrm{~cm}$, $K=0.50 \pm 0.02, t_{0}=0.08 \pm 0.03$ for the Amazonas, $L_{\infty}=75.4 \pm$ $1.1 \mathrm{~cm}, K=0.67 \pm 0.02, t_{0}=0.04 \pm 0.02$ for the Ucayali, $L_{\infty}=$ $65.8 \pm 1.0 \mathrm{~cm}, K=0.73 \pm 0.04, t_{0}=0.05 \pm 0.03$ for the Napo and $L_{\infty}=68.4 \pm 0.9 \mathrm{~cm}, K=0.64 \pm 0.04, t_{0}=0.07 \pm 0.02$ for the Putumayo. Significant growth differences were found among river basins (Fig. 6, Table 2). O. bicirrhosum had significantly greater growth in the Amazon river-basin than in the Ucayali $\left(S_{M L}=38.4, d f=3, p<0.001\right)$, the Putumayo $\left(S_{M L}=\right.$ 152.2, $d f=3, p<0.001)$ and the Napo $\left(S_{M L}=175.0, d f=3\right.$, $p<0.001)$. Fish from the Ucayali also grew significantly larger than fish from the Napo $\left(S_{M L}=100.8, d f=3, p<0.001\right)$ or Putumayo $\left(S_{M L}=60.2, d f=3, p<0.001\right)$. There was no significant growth difference between specimens from Napo and Putumayo river $\left(S_{M L}=5.6, d f=3, p>0.05\right)$. Comparing observed lengthat-age per age groups using ANOVA indicated that growth differences among river-basins were significant for every age group except the first year (ANOVA, $F=1.267, d f=2, p=0.285$ at 1 year; $F=8.805, d f=3, p<0.001$ at 2 years; $F=3.296$,

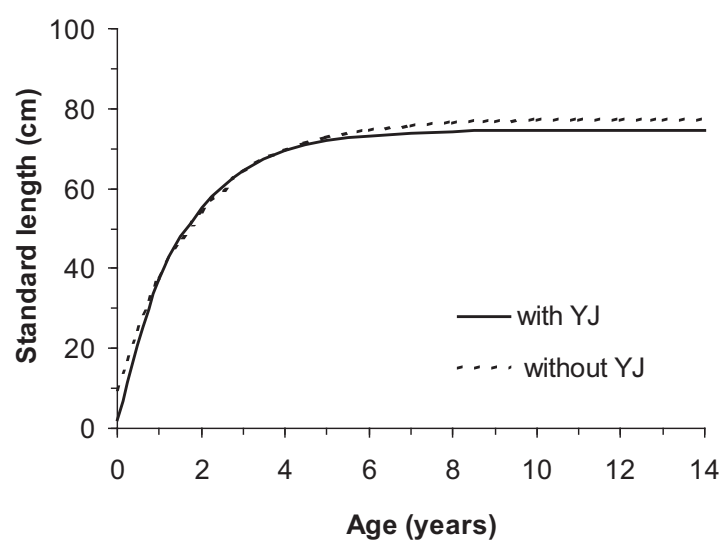

Fig. 5. Von Bertalanffy growth function of $O$. bicirrhosum females from Ucayali river, with or without yolk sac juveniles (YJ). The YJ also came from Ucayali river.

$d f=3, p=0.027$ at 3 years; Kruskal-Wallis ANOVA on ranks, $H=22.687, d f=3, p<0.001$ at 4 years; $F=16.356, d f=3$, $p<0.001$ at 5-6 years; and $H=45.214, d f=3, p<0.001$ at $>7$ years).

Growth differences among river-basins were logically magnified when expressed as body mass-at-age (Fig. 7). This was particularly striking in the Amazonas, where $O$. bicirrrhosum reached much heavier body mass $(>8 \mathrm{~kg})$ : nearly twice and three times as much as in the Ucayali-Napo and the Putumayo, respectively (Fig. 7).

\section{Discussion}

Very few studies on $O$. bicirrhosum growth have been carried out to date and the only published results come from the Mamirauá Reserve in Brasil: here, one study used annulus counts on scales (Cavalcante 2008) and another used length frequency distribution analysis (Lucena et al. 2008), with very similar results. Cavalcante (2008) claimed that two annuli formed per year in the Mamirauá Reserve, on the basis of an unconvincing marginal increment analysis. They considered that one annulus was formed during the beginning of the low water period, when a slightly decreased marginal increment was observed, and the other when the waters started to rise, which corresponded to an marginal increment increase. This species might well form two annuli a year in the Mamirauá Reserve, as seems to be the case of its closest relative, Arapaima gigas (Arantes et al. 2010; Castello et al. 2011), but the evidence provided is not adequate to confirm this. Contrastingly, in the present study carried out in different river-basin of the Peruvian Amazon with contrasted hydrological cycles, the formation of a single annulus (translucent zone) per year was observed, during the dry and early rising water periods. The formation of a single annulus during this particular period of the hydrological cycle seems to be the rule for fish species in 

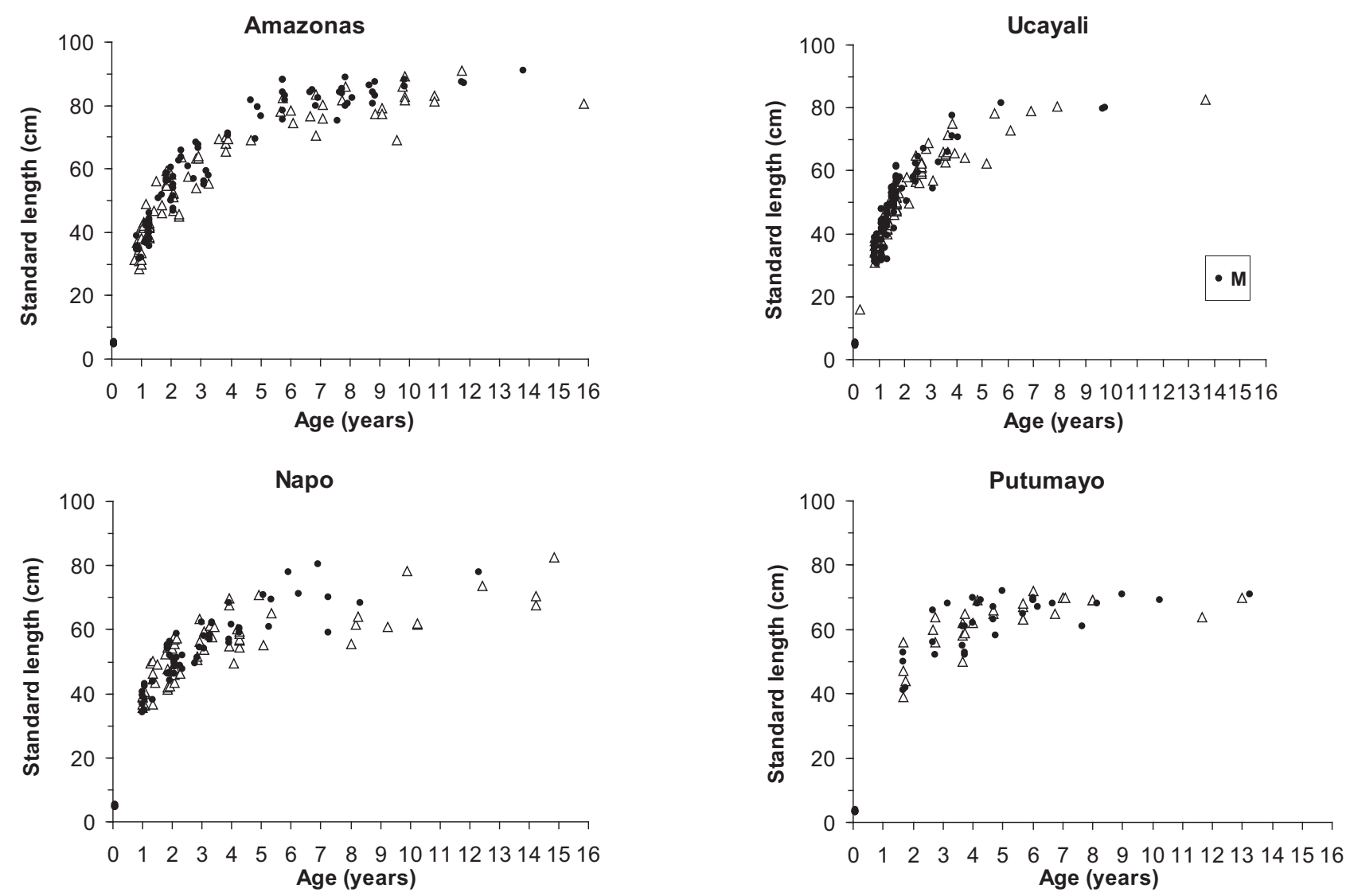

Fig. 6. Length-at-age distributions for males (black dots) and females (white triangles) Osteoglossum bicirrhosum in four river-basins of the Peruvian Amazon.

Western Amazonia, as it was already observed in Characiformes: for Pygocentrus nattereri (Duponchelle et al. 2007) in Bolivia, Prochilodus nigricans in Bolivia (Loubens and Panfili 1995) and Ecuador (Silva and Stewart 2006), and for Colossoma macropomum (Loubens and Panfili 1997), Piaractus brachypomus (Loubens and Panfili 2001), in Perciformes: Plagioscion squamosissimus (Loubens 2003), in Siluriformes: Pseudoplatystoma fasciatum and $P$. tigrinum (Loubens and Panfili 2000). O. bicirrhosum is found primarily in floodplain lakes (Goulding 1980; Val and de Almeida-Val 1995; Saint-Paulet al. 2000) and is dependent upon the flooded area for feeding (Lowe-McConnel 1964; Goulding 1980; Mascarenhas 2008). During the rainy season, the flooded area teems with insects, which are a major component of the silver arowana's diet (Lowe-McConnel 1964; Goulding 1980; Mascarenhas 2008; Ruiz Arce 2011). It is therefore likely that the high water season represents a period of favourable trophic conditions for this species, which leads to fast growth (opaque zones on otoliths), whereas the dry season corresponds to less favourable conditions and slower growth (stained translucent marks). The dry and early rising water season also corresponds to the breeding season in both river basins (Ayala 2001; Tang and Gomez 2005; Waty Unpublished data; Ruiz Arce 2011), and resource diversion towards gonad maturation during this period probably also contributes to slower growth.
The sample sizes in some localities were relatively small, particularly for the Putumayo, compared to more classical studies of fish growth (Panfili et al. 2002), and such limitations may have important effect on the validity of growth parameter estimates (see Kritzer et al. 2001). O. bicirrhosum is considered endangered in the Peruvian Amazon (Moreau and Coomes 2006) and obtaining large samples is complicated and unreasonable from a conservation point of view. Nevertheless, a particular effort was made in the present study to obtain as wide a size-spectrum as possible for both sexes and to limit the absence of some age-groups; this goal was reached everywhere but in the Putumayo, where no fish of age group-1 could be obtained. This was compensated, however, by the sampling of some very small specimens of age group 0 , which greatly improved the modelling of the growth curve. Another important point to emphasize is that, in every river basin, length-at-age plots showed that asymptotic growth was reached and lasted for about two-thirds of the observed age distributions, which suggests that the sampling of large individuals was adequate. Despite these precautions, the use of the VBGF was limited to comparative purposes and these were backed-up by analyses of observed length-at-age.

The results showed no significant growth dimorphism among sexes within basins, but indicated significant growth differences among river basins. Life history trait differences 

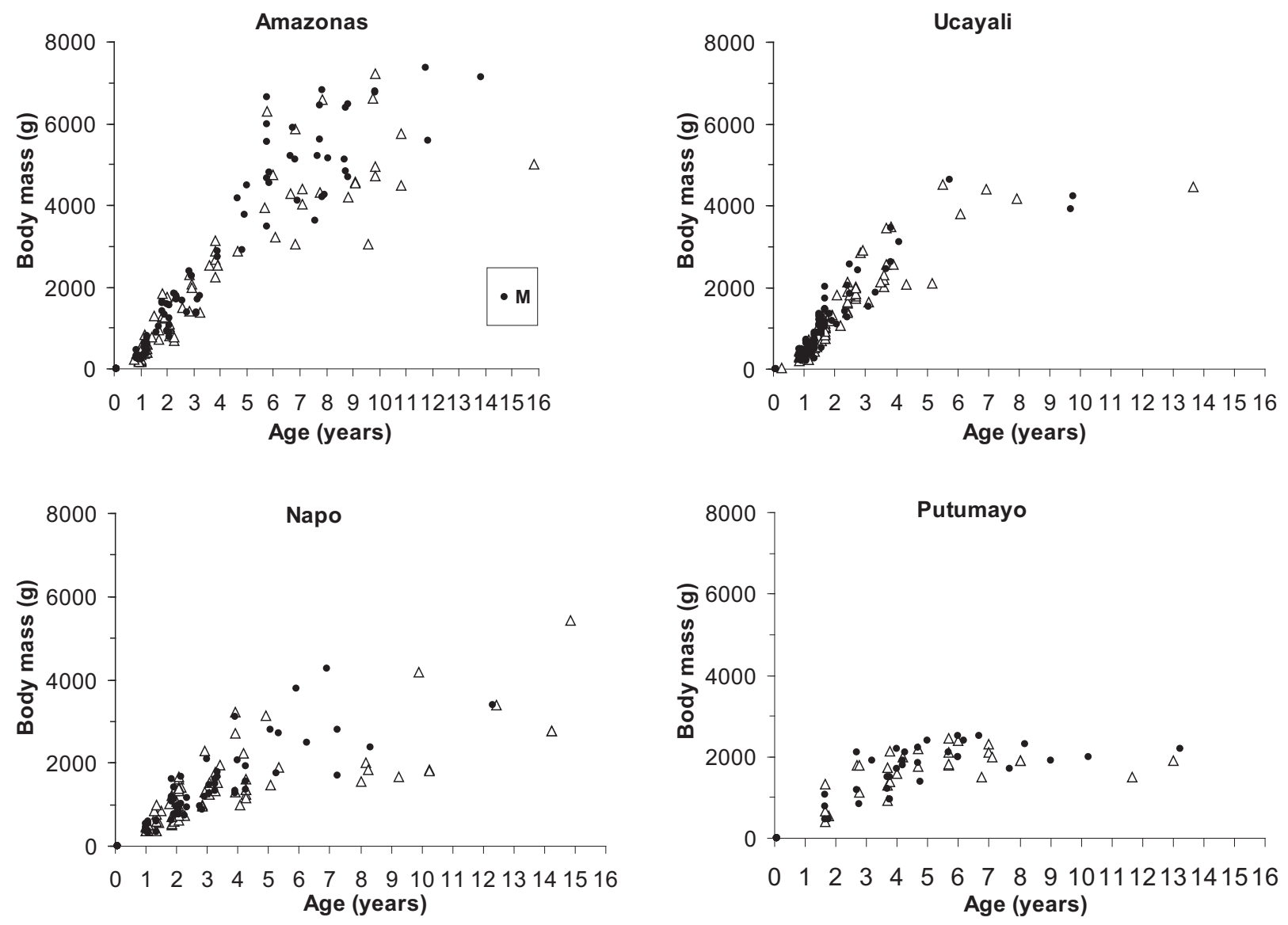

Fig. 7. Mass-at-age distributions for males (black dots) and females (white triangles) Osteoglossum bicirrhosum in four river- flood plains of the Peruvian Amazon.

among the populations of the four river basins might reflect genetic differentiation (existence of distinct populations having fixed diverging alleles, which induce different phenotypes expressed independently from the environment) or merely phenotypic plasticity to contrasting environmental conditions (Giesel 1976; Caswell 1983; Partridge and Harvey 1988; Stearns 1992). Distinguishing between these two, non-exclusive, hypotheses will require further investigations on precisely sampled localities.

The species grew quickly during the first two years, and the asymptotic phase of the growth curve was reached after four to five years, except in the Putumayo where it was reached slightly earlier. By then, the important differences in body mass observed among river basins could be explained by the maximum size differences. The growth performances observed in this study are much higher than those obtained in captive rearing conditions by Castro and Santamaria (1993), who reported an average $20.5 \mathrm{~cm}$ and $55 \mathrm{~g}$ at one-year, which correspond to fish at least $15 \mathrm{~cm}$ shorter and $350 \mathrm{~g}$ lighter than in the present study at the same age. Their rearing conditions were obviously not adequate. More recent rearing experiments resulted in fish of $\sim 45 \mathrm{~cm}$ and $\sim 520 \mathrm{~g}$ at one year (Argumedo 2005) or $\sim 25 \mathrm{~cm}$ at 4 months (Hernandez et al. 2010), i.e., better growth performances than in natural conditions, as is generally expected under controlled environmental parameters and regular food availability (Jonsson 1997; Baer et al. 2011). On the other hand, the growth parameters observed in the Mamirauá Reserve in Brasil, using scale examination (Cavalcante 2008) or length-frequency distributions (Lucena et al. 2008) are relatively similar to those obtained in the present study: $L_{\infty}=86 \mathrm{~cm}$, $K=0.48$ and $L_{\infty}=77.6 \mathrm{~cm}, K=0.54$, respectively. Although independent comparison of the VBGF parameters may lead to erroneous conclusions (see Živkov et al. 1999), the length-atage values obtained from these two Brazilian studies fall within the range of those observed in the Peruvian Amazon, with a mean length of $33-38 \mathrm{~cm}$ at one year and $76-80 \mathrm{~cm}$ at 5 years using scale observations and length distributions, respectively. These similarities tend to support Cavalcante's (2008) claim of two annuli a year in Mamirauá, which nevertheless needs to be properly demonstrated.

The main difference between this study and those carried out in the Mamirauá Reserve concerns the longevity, which was at least three times greater in the Peruvian Amazon (16 years) than in Mamirahua (5 years, Cavalcante 2008). This surprising difference could have two potential explanations. A sampling bias in the Mamirahua might have resulted in the absence of old 
specimens, but this hypothesis seems unlikely considering the fishing gears used (harpoons, gill nets and seines), the variety of environments sampled (oxbow lakes, channels, flooded forest, etc.), the size range ( $10-80 \mathrm{~cm} \mathrm{TL})$ and number of fish used in this previous study (360 fish, among which $\sim 30$ between 70 and $80 \mathrm{~cm}$ ). The alternative, more plausible, explanation would be the inability to detect rings on scales after a few years, making them unsuitable for growth studies on this species. This observation is a general rule for old fish when using scales for age estimation, with a systematic bias in older ages because growth reduction induces a compression of the structures at the scale margin (Panfili et al. 2002). Unfortunately, no photo allowing an interpretation of growth patterns on scales was presented in Cavalcante (2008), or in an earlier preliminary study (Cavalcante 2004). On the Peruvian specimens, regular, interpretable patterns could not be found on scales (Ruiz Arce 2011). Nevertheless, the longevity of $O$. bicirrhossum is likely to be greater than the 16 years observed during this study. Indeed, in some cases, otoliths of old specimens were discarded because of the difficulty of telling one annulus apart from another close to the edge, particularly with the frequent occurrence of multiple-annuli (annuli constituted of several marks), as can be observed (Fig. 3d). Moreover, the largest specimen aged was barely above $90 \mathrm{~cm} \mathrm{SL}$ in this study, yet the species can reach about $120 \mathrm{~cm} \mathrm{TL}$ ( $114 \mathrm{~cm} \mathrm{SL}$, http://www.fishing-worldrecords.com/scientificname/0steoglossum\%20bicirrhosum/show). The absence of very large specimens from our sampling and its possible consequences for the underestimation of longevity, might be a side effect of collecting in fish markets and potential gear selectivity. In the Peruvian Amazon, however, fishermen use a wide array of fishing gears, including harpoons and bows, which are not selective. When using these particular gears, fishermen tend to target the largest available fish. Moreover, as already detailed earlier, the observed length-at-age in every river-basin showed phases of asymptotic growth lasting about 10 years, which strongly suggests that the largest specimens sampled were close to the maximum sizes available in the respective river-basins. An explanation, supported by the results of the present study, might be the existence of several different populations in the Amazon river-basin, with important differences in growth. Given this hypothesis, it could be that populations with faster growth and larger individuals were not sampled in our study. Alternatively, fishing pressure might have already selected individuals, and thus large specimens are no longer found in these ecosystems.

\section{Conclusion}

This study provides a reliable, easily reproducible method for estimating the age of Osteoglossum bicirrhosum and studying their population dynamics. Despite the intensive and frequently unsustainable exploitation rates to which this species is subjected for the ornamental fish trade (Moreau and Coomes 2006, 2007), almost nothing is known about its population dynamics and structure in the Amazon river-basin. Yet, their very large distribution area and sedentary tendencies (Goulding 1980; Bayley and Petrere 1989; de Mérona and Gascuel, 1993; Reis et al. 2003) would be expected to lead to population and genetic structuring. The results of the present study indicated the existence of an important variability in the growth capabilities of the silver arowana among river-basins. This variability might result either from the phenotypic plasticity of the species due to environmental heterogeneity or from the existence of several distinct populations within Peru, that may need to be managed independently. Considering the growing concerns about $O$. bicirrhosum conservation (Moreau and Coomes 2006), there is an urgent need for comparative life history and genetics studies at the inter- and intra-basin levels in order to understand the population structuring of this species and manage it accordingly. The results presented in this study aimed to make the first step towards that goal.

Acknowledgements. This study was carried out in the Laboratoire mixte international "Evolution et Domestication de l'Ichtyofaune amazonienne (LMI-EDIA) developed by the Instituto de Investigaciones de la Amazonia Peruana (IIAP) and the Institut Français de Recherche pour le Développement (IRD), both of which are a part of the network RIIA (Red de Investigación sobre la Ictiofauna Amazónica; http://www.riiaamazonia.org/). Financial support was provided by INCAGRO (Subproyecto "Bases para el manejo sostenible y el cultivo de la arowana Osteoglossum bicirrhosum en la amazonía peruana", presentado al Concurso Público Nacional $\mathrm{N}^{\circ} 03$ - 2007 - PIEA - INCAGRO) and IRD. Special thanks go to the Instituto Nacional de Desarrollo (INADE), particularly to Luis Moya for ensuring the sampling in the Putumayo.

\section{References}

Alcántara B.F., Chu-Koo F.W., Chávez V.C.A., Tello S., Bances C.K.C.,. Torrejón M.M, Gómez N.J.L., Noriega M.J., 2007, Notas sobre la pesquería ornamental de la arahuana Osteoglossum bicirrhosum (Osteoglossidae) en Loreto, Perú y posibilidades de su cultivo. Folia Amaz. 16, 55-61.

Andrews C., 1990, The ornamental fish trade and fish conservation. J. Fish Biol. 37, 53-59.

Arantes C.C., Castello L., Stewart D.J., Cetra M., Queiroz H.L., 2010, Population density, growth and reproduction of arapaima in an Amazonian river-basin. Ecol. Freshw. Fish 19, 455-465.

Argumedo E.G., 2005, Arawanas: manual para la cria comercial en cautiverio. Florencia, Colombia, ACUICA, Fondo para la Accion Ambiental.

Ayala A.I., 2001, Ecologia reproductiva de Osteoglossum bicirrhosum Vandelli, 1829 "arahuana" en la cuenca del rio Ucayali. Ciencias en Conservacion de Recursos Forestales. Lima, Univ. Nacional Agraria La Molina.

Baer A., Schulz C., Traulsen I., Krieter J., 2011, Analysing the growth of turbot (Psetta maxima) in a commercial recirculation system with the use of three different growth models. Aquac. Int. 19, 497-511.

Bayley P.B., Petrere M., 1989, Amazon fisheries: assessment methods, current status and management options. In: Dodge D.P. 
(Ed.), Proc. Int. Large River Symposium, Can. Spec. Publ. Fish. Aquat. Sci. 106, pp. 385-398.

Carvalho de Lima A., Prang G., 2008, Demandas para o manejo e conservação do Aruanã branco, Osteoglossum bicirrhosum (Cuvier, 1829), na região do Medio Solimões. In: Queiroz H.L., Camargo M. (Eds.), Biologia, Conservação e Manejo dos Aruanãs na Amazônia Brasileira. Téfé, Brasil, Instituto de Desemvolvimiento Sustentavel de Mamirauá, pp. 15-26.

Castello L., Stewart D.J., Arantes C.C., 2011, Modeling population dynamics and conservation of arapaima in the Amazon. Rev. Fish Biol. Fish. 21, 623-640.

Castro D.M., Santamaria C.A., 1993, Notas preliminares sobre el desarrollo de la Arawana (O. bicirrhosum) (Vandelli 1829) en estanques de tierra. Colombia Amazónica 6, 47-59.

Caswell H., 1983, Phenotypique plasticity in life-history traits: demographic effects and evolutionary consequences. Am. Zool. $23,35-46$.

Cavalcante D., 2004, Marcas de crescimento aplicadas ao estudo de maturação sexual do aruanã (Osteoglossun bicirrhosum) Vandelli, 1829, na reserva de desenvolvimento sustentável Mamirauá. Post-Grado em Ciencia Animal: Ecologia Aquática e Aquicultura Univ. Federal do Para.

Cavalcante D., 2008, Crescimiento e maturação sexual de Aruanãs brancos (Ostoglossum bicirrhosum) em Mamirauá. In: Queiroz H.L., Camargo M. (Eds.), Biologia, Conservação e Manejo dos Aruanãs na Amazônia Brasileira. Téfé, Brasil, Instituto de Desemvolvimiento Sustentavel de Mamirauá, pp. 105-117.

Chang W.Y.B., 1982, A statistical method for evaluating the reproducibility of age determination. Can. J. Fish. Aquat. Sci. 39, 12081210.

Chaves R., Camargo M., Queiroz H.L., 2008, Estudos ecologicos do aruanã branco Ostoglossum bicirrhosum em areas inundaveis do Médio Rio Solimões. In: Queiroz H.L., Camargo M. (Eds.), Biologia, Conservação e Manejo dos Aruanãs na Amazônia Brasileira. Téfé, Brasil, Inst. Desemvol. Sustentavel de Mamirauá, pp. $75-85$.

Duponchelle F., Lino F., Hubert N., Panfili J., Renno J.F., Baras, Torrico J.P., Dugué R., Nuñez J., 2007, Environment-related life history trait variations of the red-bellied piranha, Pygocentrus nattereri, in two river basins of the Bolivian Amazon. J. Fish Biol. 71, 1113-1134.

Garcia A., Tello S., Vargas G., Duponchelle F., 2009, Patterns of commercial fish landings in the Loreto region (Peruvian Amazon) between 1984 and 2006. Fish Physiol. Biochem. 35, 53-67.

Giesel J.T., 1976, Reproductive strategies as adaptations to life in temporally heterogeneous environments. Ann. Rev. Ecol. Syst. 7, 57-79.

Goulding M., 1980, The fishes and the forest. Explorations in Amazonian natural history. Berkeley, University of California Press.

Hernandez C., Gomez E., Hurtado H., 2010, Estudio preliminar del levante de juveniles de Arawana plateada (Osteoglossum bicirrhosum) en sistemas cerrados de recirculación. Rev. Fac. Cienc. Bas. 6, 96-113.

Jonsson B., 1997, A review of ecological and behavioural interactions between cultured and wild Atlantic salmon. ICES J. Mar. Sci. 54, 1031-1039.

Kimura D.K., 1980, Likelihood methods for the Von Bertalanffy growth curve. Fish. Bull. 77, 765-776.
Kritzer J.P., Davies C.R., Mapstone B.D., 2001, Characterizing fish populations: effects of sample size and population structure on the precision of demographic parameter estimates. Can. J. Fish. Aquat. Sci. 58, 1557-1568.

Loubens G., Panfili J., 1995, Biologie de Prochilodus nigricans (Teleostei: Prochilodontidae) dans le bassin du Mamoré (Amazonie bolivienne). Ichthyol. Explor. Freshw. 6, 17 - 32.

Loubens G., Panfili J., 1997, Biologie de Colossoma macropomum (Teleostei: Serrasalmidae) dans le bassin du Mamoré (Amazonie bolivienne). Ichthyol. Explor. Freshw. 8, 1-22.

Loubens G., Panfili J., 2000, Biologie de Pseudoplatystoma fasciatum et $P$. tigrinum (Teleostei: Pimelodidae) dans le bassin du Mamoré. Ichthyol. Explor. Freshw. 11, 13-34.

Loubens G., Panfili J., 2001, Biologie de Piaractus brachypomus (Teleostei: Serrasalmidae) dans le bassin du Mamoré (Amazonie bolivienne). Ichthyol. Explor. Freshw. 12, 51-64.

Loubens G., Panfili J., 2003, Biologie de Plagioscion squamosissimus (Teleostei: Scianidae) dans le bassin du Mamoré (Amazonie bolivienne). Ichthyol. Explor. Freshw. 12, 51-64.

Lowe-McConnell R.H., 1964, The fishes of the Rupununi savanna district of Bristish Guiana, South America. Part 1. Ecological groupings of fish species and effects of the seasonal cycle on the fish. J. Linn. Soc. (Zool.) 45, 103-144.

Lucena F., Cavalcante D., Sobanski M.B., 2008, Dinâmica populacionale avaliação do estoque do Aruanã, Ostoglossum bicirrhosum (Cuvier 1829) do Médio Solimões (Reserva de Desemvolvimiento Sustentavel de Mamirauá). In: Queiroz H.L., Camargo M. (Eds.), Biologia, Conservação e Manejo dos Aruanãs na Amazônia Brasileira. Téfé, Brasil, Instituto de Desemvolvimiento Sustentavel de Mamirauá, pp. 141-152.

Mascarenhas R., 2008, Analise da alimentacção natural do Aruanã branco (Ostoglossum bicirrhosum) na Reserva de Desemvolvimiento Sustentavel de Mamirauá (RDSM). In: Queiroz H.L., Camargo M. (Eds.), Biologia, Conservação e Manejo dos Aruanãs na Amazônia Brasileira. Téfé, Brasil, Instituto de Desemvolvimiento Sustentavel de Mamirauá, pp. 87-103.

Mérona B. de, Gascuel D., 1993, The effects of flood regime and fishing effort on the overall abundance of an exploited fish community in the Amazon floodplain. Aquat. Living Resour. 6, $97-$ 108.

Mojica J.I., Castellanos C., Usma J.S., Álvarez R., 2002, Libro rojo de peces dulceacuícolas de Colombia. Bogotá, Instituto de Ciências Naturales, Univ. Nac. Colômbia y Ministério del Médio Ambiente.

Moreau M.A., Coomes O.T., 2006, Potential threat of the international aquarium fish trade to silver arawana Osteoglossum bicirrhosum in the Peruvian Amazon. Oryx 40, 152-160.

Moreau M.A., Coomes O.T., 2007, Aquarium fish exploitation in western Amazonia: conservation issues in Peru. Environ. Conserv. 34, 12-22.

Ng P.K.L., Tan H.H., 1997, Freshwater fishes of Southeast Asia: potential for the aquarium fish trade and conservation issues. Aquat. Sci. Conserv. 1, 79-90.

Olivier K., 2001, The Ornamental Fish Market Research Programme. FAO/Globefish, United Nations Food and Agriculture Organisation, Rome, $\mathrm{n}^{\circ} 67$.

Ortiz N., Iannacone J., 2008, Estado actual de los peces ornamentales amazónicos del Perú que presentan mayor demanda de exportación. Biologist (Lima) 6, 54-67. 
Panfili J., Pontual H. de, Troadec H., Wright P.J., 2002, Manual of fish sclerochronology. Ifremer-IRD.

Partridge L., Harvey P.H., 1988, The ecological context of life history evolution. Science $241,1449-1455$.

Prang G., 2008, An industry analysis of the freshwater ornamental fishery with particular reference to the supply of Brazilian freshwater ornamentals to the UK market. Uakari 3, 7-51.

Queiroz H.L., 2008, Investimento parental e reprodução do Aruanã branco, Osteoglossum bicirrhosum, na Reserva Mamirauá. In: Queiroz H.L., Camargo M. (Eds.), Biologia, Conservação e Manejo dos Aruanãs na Amazônia Brasileira. Téfé, Brasil, Inst. Desemvolv. Sustentavel de Mamirauá, pp. 119-132.

Reis R.E., Kullander S.O., Ferraris C.J., 2003, Checklist of freshwater fishes of South and Central America. Porto Alegre, Edipucrs.

Ruiz Arce A., 2011, Historia de vida de la arahuana, Osteoglossum bicirrhosum (Cuvier, 1829) en tres cuencas de la Amazonia Peruana. MSc. Thesis, Univ. Nac. Mayor de San Marcos, Lima.

Saint-Paul U., Zuanon J., Villacorta Correa M.A., Garcia M., Noemi Fabre N., Berger U., Junk W.J., 2000, Fish communities in central white- and blackwater floodplains. Environ. Biol. Fish. 57, 235-250.
Silva E.A., Stewart D.J., 2006, Age structure, growth and survival rates of the commercial fish Prochilodus nigricans (bocachico) in North-eastern Ecuador. Environ. Biol. Fish. 77, 63-77.

Stearns S.C., 1992, The evolution of life histories. New York, Oxford University Press.

Tang M., Gomez J.L., 2005, Biologia y aprovechamiento del arahuana, Osteoglossum bicirrhosum en la micro cuenca de lacocha El Dorado, Reserva Nacional Pacaya Samiria. Fac. Cienc. Biol. Iquitos, Univ. Nac. Amazonia Peruana.

Tello M.S., Cánepa J.R.L.S., 1991, Estado actual de la explotación de los principales peces ornamentales de la Amazonía Peruana. Folia Amaz. IIAP 3, 109-128.

Tomassone R., Dervin C., Masson J.P., 1993, Biométrie : modélisation de phénomènes biologiques. Paris, Masson.

Val A.L., de Almeida-Val V.M.F., 1995, Fishes of the Amazon and their environment. Berlin, Springer Verlag.

Živkov M.T., Trichkova T.A., Raikova-Petrova G.N., 1999, Biological reasons for the unsuitability of growth parameters and indices for comparing fish growth. Environ. Biol. Fish. 54, 67-76. 